\title{
DA BOSSA NOVA À TROPICÁLIA: contenção e excesso na música popular*
}

\section{Santuza Cambraia Naves}

Em 1968, Augusto de Campos reuniu no livro Balanco da bossa: antologia crítica da moderna música popular brasileira uma série de artigos seus e de músicos como Júlio Medaglia e Gilberto Mendes, publicados anteriormente em suplementos literários de jornais paulistas, que analisam, entre outras experiências musicais recentes, como a da tropicália, o estilo desenvolvido pelos bossanovistas. Estes autores, a propósito de defender uma postura internacionalista e moderna na música popular, em contraposição aos ideólogos do "nacional-popular", ressaltam a atitude inovadora dos criadores da bossa nova, particularmente a figura de João Gilberto. Eles são unânimes em atribuir a João Gilberto uma postura que valoriza a contenção, contrária ao emocionalismo excessivo da música popular das décadas de 40 e 50, e em estabelecer uma correspondência entre este procedimento e outras manifestações estéticas dos anos

* Para a realização da pesquisa que deu origem a este texto contei com a colaboração das pesquisadoras do Centro de Estudos Sociais Aplicados (CESAP), da Universidade Candido Mendes, Juliana de Mello Jabor, Maria Micaela Bissio Neiva Moreira e Thais Medeiros. Fui também auxiliada por Heloísa Tapajós e Kate Lyra. Agradeço a todas.
50, como a poesia concreta e a arquitetura de Oscar Niemeyer. Assim, segundo eles, ao introduzir um registro musical intimista semelhante ao do cool jazz, a bossa nova harmonizar-se-ia com o ideário de racionalidade, despojamento e funcionalismo que teria caracterizado várias manifestações culturais do período. Vale acrescentar que se valoriza, nesta tendência, o procedimento bossa-novista de ruptura com tradições anteriores da música popular no Brasil. Assim, tal como os poetas concretos, que teriam rompido com as tradições retóricodiscursiva e subjetivista na literatura, os músicos da bossa nova, notadamente João Gilberto, pautariam o seu trabalho pela rejeição dos sambas-canções e dos boleros melodramáticos do período anterior, e da maneira operística de interpretar estas canções, ao estilo de Dalva de Oliveira e outros cantores do período.

Este tipo de interpretação, desenvolvida pelos poetas e musicólogos paulistas, tornou-se, de certa forma, canônica, passando a constituir uma referência imprescindível para os estudiosos da música popular no Brasil. Mas observa-se que, a despeito da profundidade e pertinência destas análises, elas acabam absolutizando o período inicial da bossa nova, em que, de fato, sob a batuta de João 
Gilberto, parte-se para um tipo de experimentação musical bastante afinada com as propostas da poesia concreta. Assim, por exemplo, vemos que as músicas inaugurais da nova tendência musical aparecem como canções-manifesto. "Desafinado" (1958) e "Samba de uma nota só" (1960), compostas por Tom Jobim, em parceria com Newton Mendonça, introduzem um tipo de procedimento em que letra e música, ao mesmo tempo em que se comentam mutuamente, fazem alusões às novidades musicais. Os elementos de transgressão da bossa nova encontram-se presentes sobretudo em "Desafinado": no momento exato em que se pronuncia a sílaba tônica da palavra "desafino" ocorre, no plano da música, uma nota inesperada, que representa uma transgressão aos padrões harmônicos da música popular convencional. Outro procedimento que caracteriza as duas composições, colocando-as em correspondência com o tipo de sensibilidade da poesia concreta, é a maneira cool de se lidar com a temática amorosa. Em "Desafinado", por exemplo, a pretexto de uma arenga sentimental, discute-se, na verdade, uma questão estética.

Tudo leva a crer, portanto, que a "bossa nova" que interessa aos concretos é a que se singulariza pelo intimismo, pela concisão, pela racionalidade e pela objetividade, o que converge perfeitamente com a proposta de João Gilberto. E é justamente neste ponto que eu gostaria de acrescentar alguns dados à discussão, chamando a atenção para outros aspectos do que se convencionou chamar de "estilo bossa-nova". Poderia lembrar, num primeiro momento, que nem todos os integrantes da bossa nova se sentiam atraídos, como João Gilberto, por um procedimento de ruptura mais radical com o passado da música popular, embora todos reconhecessem uma liderança na figura deste músico, principalmente com relação à famosa "batida" que ele inventa no violão e à sua maneira de cantar à meia voz, com um timing perfeito e nenhuma ênfase emotiva. Dito de outro modo, a bossa nova permite diversas leituras, principalmente por parte dos músicos que participaram desta tendência. Se há uma unanimidade entre eles quanto à percepção de João Gilberto como um líder, cada um, porém, acena para procedimentos diferentes com relação às tradições incorporadas. Assim, por exemplo, todos ad- mitem a influência do jazz mais requintado que se desenvolve nos Estados Unidos a partir dos anos 40, do be-bop ao cool jazz, sobre os músicos que se propõem a recriar o samba nativo. Mas alguns, mais do que outros, reconhecem o impacto do bolero, principalmente o desenvolvido no México, com Lucho Gatica. Roberto Menescal, por exemplo, ao falar sobre as novidades estrangeiras que o marcaram profundamente na fase de sua formação musical, refere-se ao LP Inolvidable, de Lucho Gatica, que recorria apenas a dois instrumentos — violão e baixo - para o arranjo, rompendo com a tradição do bolero de utilizar grandes orquestrações. Segundo Menescal, este procedimento foi importante para que ele e outros músicos de sua geração formassem o hábito de "ouvir o violão", que assim, dialogando apenas com o baixo, aparece destacado, singularizado. ${ }^{1}$

Carlos Lyra também se refere às músicas mexicanas, como os boleros de Agustin Lara, que seriam referências importantes para ele e os seus companheiros de geração. E vê de maneira carinhosa o repertório anterior de sambas-canções, que denomina de "boleros brasileiros", embora distinga, dentro desta tradição, os mais "sofisticados" e os melodramáticos. Assim, segundo ele, Antônio Maria incorreria nos dois procedimentos, criando canções pesadas, como "Ninguém me ama", e composições refinadas como "Ser ou não ser" e "Um cantinho e você". Lyra admite que "desperta" para a música ouvindo os sambascanções interpretados por Dick Farney, e que começa a sua carreira musical compondo neste gênero, como é o caso de "Quando chegares" e mesmo de "Minha namorada", "meio sambacanção", uma espécie de música de transição para a bossa nova. Esse estilo musical teria então, segundo ele, uma gama variada de influências: além do bolero mexicano, do impressionismo de Ravel e Debussy, do jazz desenvolvido por Gershwin, Cole Porter, Richard Rogers, Larry Hart e vários outros compositores. Às influências estrangeiras somam-se as misturas brasileiras de samba, xaxado, valsa, além de outros ritmos. Enfim, para Lyra, se João Gilberto é mais identificado como cantador de samba, existem outros ritmos dentro da bossa nova, da valsa ao baião. ${ }^{2}$ 
José Miguel Wisnik, em seu livro o Coro dos contrários (1983), identificou dois procedimentos modernistas fundamentais: de um lado, um rigor construtivo, como o de Webern, que recorre ao mito do engenheiro, e de outro, o recurso à bricolagem, tão caro a Stravinski, Villa-Lobos e outros compositores da época. Analisando $O$ pensamento selvagem, de Lévi-Strauss (1989), Jacques Derrida (1971) define o "engenheiro" como "um sujeito que fosse a origem absoluta do seu próprio discurso e o construísse 'com todas as peças"'. Em trabalho anterior (Naves, 1998), argumentei que o mito do engenheiro não teve lugar na experiência modernista brasileira porque tanto os músicos quanto os poetas do movimento tenderam a assumir uma postura antropofágica — semelhante à preconizada por Oswald de Andrade em manifesto (1972) ajustando-se mais ao perfil do bricoleur delineado por Lévi-Strauss: um tipo de produtor que se define pela maneira incorporativa de realizar suas operações, utilizando sempre os instrumentos já disponíveis, ao contrário do engenheiro, que subordina cada tarefa específica "à obtenção de matériasprimas e de utensílios concebidos e procurados na medida do seu projeto" (Lévi-Strauss, 1989, p. 33). As imagens fortes trazidas à baila por Lévi-Strauss, como a do caleidoscópio ou da colagem - sucessivas configurações de imagens obtidas mediante a combinação de um certo número de textos visuais - ajudaram-me a pensar na possibilidade modernista de se atingir a modernidade sem recorrer à tábula rasa, procurando-se, ao contrário, criar o "tipo novo" através de arranjos que atualizam repertórios variados, porém finitos, de nossa tradição cultural (Lévi-Strauss, 1989, p. 52). O que mais me interessava nesta discussão era justamente ressaltar o fato de que os músicos e os poetas modernistas, no Brasil, partilhavam uma mesma visão do país, qual seja, a de um universo inesgotável de informações culturais, tanto arcaicas quanto contemporâneas, tanto regionais quanto universais. A esta imagem de pujança seguia-se, naturalmente, a idéia de se tentar incorporar a riqueza cultural ao trabalho artístico.

Associei o procedimento excludente de João Gilberto, ao inaugurar um estilo conciso e racional que rompia com formas musicais anteriores, ao registro do engenheiro, retirado de uma mitologia que pressupõe um marco zero, a partir do qual tudo se cria por vontade - e projeto - de um demiurgo. João Gilberto, à maneira de um demiurgo, teria dado forma à bossa nova, mesmo porque este tipo de criação musical não resultou propriamente de um projeto, embora tenha sido compartilhada por vários músicos. Em outras palavras, nos vários relatos sobre a bossa nova, João Gilberto sempre aparece como o "autor" de um estilo: a "batida" que cria ao violão e a sua maneira única de interpretar. Se tudo indica, por exemplo, que ele captou o gosto emergente pelo jazそ camerístico, não há dúvida, por outro lado, de que a nova forma musical da bossa nova em muito se deveu à sua obsessão por um ritmo e uma harmonia inteiramente novos, compatíveis com a sua interpretação dos tempos modernos (Castro, 1991). Assim, João Gilberto incorporou repertórios tradicionais, recriando, rítmica e harmonicamente, sambas de diversos autores por meio da fusão com o jaz\%: Por outro lado, ele rompeu com os gêneros associados ao excesso em várias de suas manifestações na música popular, como o "exibicionismo operístico" (expressão cunhada por Augusto de Campos, 1968) e os arranjos que recorriam a orquestrações grandiosas.

Retomo, no entanto, o argumento de que o estilo bossa-nova não se exaure com a estética de João Gilberto, mostrando-se, pelo menos do ponto de vista de músicos ligados a esta tendência, bastante diversificado. Recorro, a título de exemplo, à figura de Tom Jobim. Se ninguém tem dúvidas quanto à influência de João Gilberto sobre Tom, pelo menos no momento inicial da bossa nova, não se pode esquecer, no entanto, que este compositor havia começado a sua carreira musical num momento anterior às inovações do final dos anos 50. O próprio Tom declarou em entrevista, em 1968, que a bossa nova foi apenas uma fase na sua carreira; $80 \%$ de suas composições - entre elas "canções de câmara, fundo de filmes, música sinfônica, muito samba-canção, muito choro" não se enquadram no gênero. ${ }^{3}$

De fato, Tom inicia a sua formação musical, por volta dos 13 anos, dentro dos parâmetros da música erudita. Seu primeiro professor foi Hans Joachim Koellreuter, o músico alemão refugiado do 
nazismo que introduziu o dodecafonismo no Brasil. Segundo depoimento de Koellreuter, ele teria passado a Tom noções de harmonia e contraponto clássicos e "rudimentos de execução pianística", pois o que interessava ao professor era dar ao aluno uma instrução "globalizante" (Koellreuter apud Cabral, 1997, p. 45). Mais tarde, Tom estudou piano clássico com Lúcia Branco, Tomás Gutierrez de Terán (amigo pessoal de Villa-Lobos) e Paulo Silva. Desde cedo, mostrou-se desestimulado com o ensino "escolástico" da Escola Nacional de Música, o que o fazia recorrer a professores particulares. Ainda jovem, começou a se interessar por orquestração, passando a freqüentar o Teatro Municipal e a comprar partituras e gravações de músicos que o entusiasmavam no momento, como Stravinsky, Schoenberg e Prokofiev. Por razões de sobrevivência, trabalhou, no início da década de 50, como pianista nos "inferninhos" de Copacabana, até conseguir um emprego na Continental, onde, escrevendo partituras para compositores e fazendo arranjos para orquestra, entrou em contato com outros arranjadores, como Radamés Gnattali, Gaya, Léo Peracchi e Lyrio Panicalli. ${ }^{4}$

Chama particularmente a atenção, na trajetória artística de Tom Jobim, a sua tendência a dar continuidade, dentro do campo popular, a uma tradição musical "erudita" que, se não foi inaugurada, pelo menos foi muito marcada pelo modernismo nacionalista de Villa-Lobos. Trata-se de uma tradição que recorre ao excesso - tanto sinfônico quanto coral - como forma de representar um Brasil exuberante, pujante em seus elementos físicos e culturais (Naves, 1998). Quanto a esta interseção entre o erudito e o popular em prol de uma estética grandiosa, alguns músicos aparecem como mediadores entre Villa-Lobos e Tom Jobim, como é o caso de Tomás Terán e Radamés Gnattali. Terán, pianista espanhol, viajou para o Brasil aos 27 anos em função do seu fascínio pela obra de Villa-Lobos, particularmente pela peça $A$ prole do bebê, que ouviu em Buenos Aires executada por Arthur Rubinstein. A partir deste primeiro impacto, especializa-se em Villa-Lobos, a quem conheceu em 1924, em Paris. De volta à Europa, executa as obras do compositor brasileiro na capital francesa e, convidado por Villa-Lobos para lecionar no
Conservatório de Música e na Sociedade de Cultura Artística do Rio de Janeiro, vem morar no Brasil no início dos anos 30 (Cabral, 1997).

$\mathrm{Na}$ condição de professor de piano de Tom Jobim, Terán ressalta a importância de Radamés Gnattali na sua própria formação musical. Tom vem a ter contato mais estreito com Radamés em 1954, por ocasião da gravação da Sinfonia do Rio de Janeiro (Tom Jobim-Billy Blanco), da qual este fora arranjador, e no ano seguinte, na Continental, onde Tom se afirmaria como seu discípulo na arte de orquestrar composições populares (Cabral, 1997). Porém, mais do que uma mera questão técnica de instrumentação, Tom compartilha com o mestre duas atitudes: uma, a de transitar - como músico, compositor e arranjador - com desenvoltura pelos domínios do erudito e do popular; outra, a de se permitir experimentar os mais diversos estilos, operando tanto no registro da simplicidade quanto na estética do excesso. Esta maneira de atuar, característica de Radamés, permitiu que ele fizesse uma verdadeira revolução nos arranjos de música popular a partir do início dos anos 30. Até a intervenção do maestro, as execuções de música popular limitavam-se ao acompanhamento dos "regionais", conjuntos musicais pobremente constituídos, tanto em termos numéricos quanto criativos. A partir das experimentações instrumentais de Radamés - ao lado de Pixinguinha, na Victor, a partir de 1932 —, com sua formação adquirida nos estudos de instrumentação erudita, como pianista e violista, os arranjos de música popular recebem elementos da orquestra sinfônica e do jazz: Radamés deu continuidade a este tipo de experimentação instrumental por muitos anos, na Columbia, e posteriormente na Rádio Nacional, nas décadas de 40 e 50 (Didier, 1996).

A análise da trajetória musical de Radamés tem grande importância para o trabalho que desenvolvo na medida em que permite identificar, no compositor, um gesto modernista. Tal como os modernistas musicais da geração que o precedeu, Radamés preocupa-se em criar, por meio da música, um "idioma nacional". Suas composições, tais como as de Villa-Lobos e outros compositores, alimentam-se do repertório popular. Os músicos da geração modernista propriamente dita, entre- 
tanto, mostram-se bastante presos ao registro erudito e tendem a incorporar preferencialmente as peças folclóricas, rejeitando, por questões programáticas, a música popular produzida pela mídia o "popularesco", segundo Mário de Andrade (Mariz, 1983). Talvez até pelas dificuldades de sobreviver como músico erudito no Rio de Janeiro, Radamés aproxima-se cada vez mais da música popular, trabalhando como pianista em cinemas e teatros e, posteriormente, como vimos, como violista e arranjador. Nestes ambientes noturnos, faz amizade com músicos populares, como Luciano Perrone, Pixinguinha e outros chorões, além dos "pianeiros" da Casa Vieira Machado, na rua do Ouvidor, "de quem transcreve músicas para a partitura e com quem aprende um jeito brasileiro de tocar piano que, na época, existia somente no Rio de Janeiro" (Didier, 1996, p. 16). Assim, além de se tornar "criador" de música popular, compondo choros e outros gêneros, Radamés interfere na execução deste tipo de música, alterando-lhe o caráter com arranjos requintados. Carlos Didier lembra que ele atua também num procedimento inverso, que é o de levar para a música erudita os elementos das rodas de choro, dos pianeiros e das jazz bands norte-americanas. E, segundo Didier, é na Rádio Nacional que Radamés amadurece como orquestrador e compositor, exercitando livremente a sua criatividade com novas experimentações musicais. Trabalhando com músicos da estatura de Léo Peracchi, Romeu Ghipsman e Lyrio Panicalli, ali ele "compõe e arranja para trios, quartetos, quintetos, explora novos timbres" (Didier, 1996, pp. 23-24).

Radamés atua também, principalmente a partir dos anos 40, como uma espécie de mediador entre estilos musicais mais sofisticados e a música brasileira, estilizando o samba através do recurso à orquestra de cordas e a um tipo de harmonia proveniente da música erudita e do jaz: Consta que esta mistura produzida pelo compositor-arranjador teria sido um parâmetro para os músicos que, no final dos anos 50, partiram para a experiência bossa-novista (Didier, 1996). Data, por exemplo, de 1954, como vimos, uma maior aproximação de Radamés com Tom Jobim, a propósito da gravação da Sinfonia do Rio de Janeiro, obra composta por Tom e Billy Blanco que seria lançada no mesmo ano pela Continental, com arranjos de Radamés e sob a regência de Tom. A peça consiste de vários movimentos, cada qual tematizando aspectos da natureza e da cultura do Rio de Janeiro. E os intérpretes foram os mais variados, como Dick Farney, Gilberto Milfont, Elisete Cardoso e Emilinha Borba, entre outros. Concebida à maneira de um musical, a Sinfonia do Rio de Janeiro é comparável, segundo Jaime Negreiros, crítico musical de expressão na época, a Um americano em Paris, de Gershwin (Cabral, 1997). Radamés ressalta os aspectos da composição que celebram o Rio de Janeiro — "a montanha, o sol, o mar", "o morro" e o "asfalto, o samba e outros aspectos da cidade" - misturando instrumentos sinfônicos com os utilizados na execução de música popular: "cordas, metais, madeiras, bells, acordeom, quarteto e piano, baixo, violão elétrico e bateria com escovinha" (Didier, 1996, pp. 27-28).

A partir de 1955, com a ida de Tom Jobim para a Continental, onde passa a fazer arranjos orquestrais, a semelhança de sua trajetória com a de Radamés torna-se ainda mais marcante. Não é por acaso, portanto, que neste mesmo ano Tom é convidado por Radamés a participar do programa Quando os maestros se encontram, na Rádio Nacional, onde rege a peça sinfônica Lenda, que compôs em memória de seu pai, Jorge Jobim (Cabral, 1997).

Mas não só de peças sinfônicas vivia o jovem compositor. A primeira composição de Tom a ser gravada, em 1953, por Maurici Moura (pela Sinter, em 78 rotações), é o samba-canção "Incerteza", que faz em parceria com Newton Mendonça. Sérgio Cabral (1997) comenta que esta música se identifica muito com o clima dos anos 50, principalmente a letra, que narra o sofrimento de um protagonista de um caso de amor. Além de sambascanções soturnos, Tom, muito versátil neste momento inicial de sua carreira, parte também para outras experiências no gênero, como "Teresa da praia" (em parceria com Billy Blanco), que compõe em 1954 a pedido de Dick Farney, para cantar em dupla com Lúcio Alves. Nesta canção, letra e música se harmonizam para expressar uma situação conflituosa e ao mesmo tempo carinhosa entre dois amigos em idílio com a mesma musa da praia do Leblon. Ao invés do clima noir de "Incerteza", 
em que se vive "uma noite sem Lua", "Teresa da praia" é solar, concebida com muito espírito. Assim, os dois amigos desistem da disputa pela musa e resolvem "Teresa na praia deixar/ aos beijos do Sol/ e abraços do mar". A música, um sambacanção concebido à maneira de um sambablue (Cabral, 1997), contribui bastante para a leveza e o humor da composição.

Tom Jobim demonstra, portanto, desde o início de sua carreira, que não tem um perfil musical definido por um único tipo de sensibilidade. Se exibe, sem dúvida, uma certa vocação para a produção de composições exuberantes, ao estilo sinfônico, também se mostra apto a criar peças mais intimistas, como é o caso de "Teresa da praia". Mas tudo indica que a sua tendência ao excesso se manifesta desde cedo, principalmente se consideramos os relatos sobre os seus exercícios musicais, no final dos anos 40, com obras de Gershwin, Ravel, Debussy e Villa-Lobos, entre outros, e sobre o seu "fascínio" com a descoberta dos compositores russos Rachmaninoff, Prokofiev e Stravinsky (Cabral, 1997).

Voltando ao ponto inicial da discussão, Tom Jobim, de fato, envolve-se com o estilo bossanovista, chegando a compor, com Newton Mendonça, "Desafinado" e "Samba de uma nota só", canções lapidares da tendência e profundamente afinadas com o espírito intimista que João Gilberto pretende conferir à nova experiência musical. Mas o encontro entre Tom Jobim e João Gilberto não teria sido isento de tensões, como relata Ruy Castro ao descrever a produção do LP Canção do amor demais, de 1958, considerado um marco da bossa nova. As diferenças entre os artistas envolvidos no projeto - João Gilberto, Tom Jobim, Vinícius de Moraes, Elisete Cardoso, além dos músicos instrumentistas - quanto à concepção e realização do disco se fizeram sentir desde o início. Se João Gilberto buscava novas linguagens, os demais integrantes do grupo orientavam-se por um estilo mais convencional (pelo menos na visão de João Gilberto). João Gilberto não gostava da "gravidade" com que Elisete interpretava as músicas, assim como não apreciava a letra de Vinícius para "Serenata do adeus", que considerava de mau gosto. E, na verdade, o encontro de Tom com Vinícius, por volta de 1956, quando foi chamado para musicar a peça Orfeu do Carnaval, já havia marcado decisivamente a sua carreira. Em seguida, Vinícius the solicitou as músicas para o filme Orfen negro, dirigido por Marcel Camus, que acabou premiado em vários países e divulgou a obra de Tom no exterior. Foi a partir daí que o compositor se tornou conhecido pelo grande público (Castro, 1997).

Mas o fato é que, passado o período inicial da bossa nova, Tom retoma a sua vocação para o excesso e volta a recorrer à costumeira visão modernista do Brasil como o locus por excelência da vitalidade, um país fértil em elementos naturais e culturais. Aliás, a própria estética bossa-novista passa a conviver com a recuperação do excesso como representação de pujança cultural, como o demonstra o seu desenvolvimento nos anos 60. A princípio, com a estética do CPC da UNE, em que se busca juntar o ritmo da bossa nova com outras informações musicais, notadamente as nordestinas, ou mesmo com as configurações musicais na linha afro, desenvolvidas por músicos como Jorge Ben e Baden Powell. E logo em seguida, com a geração que surge em meados dos anos 60, representada tanto por cancionistas quanto por músicos instrumentais, como Chico Buarque de Hollanda, Edu Lobo, Caetano Veloso e Gilberto Gil.

Chico Buarque é um bom exemplo de músico da geração pós-bossa-nova que não só incorpora a "batida" inaugurada por João Gilberto como adiciona a este ritmo outros elementos do repertório musical brasileiro (Moreira, 1999). Chico admite explicitamente que, por volta dos 15 anos, ao ouvir pela primeira vez João Gilberto interpretando "Chega de saudade", converteu-se à bossa nova: "Foi aí que eu peguei em um violão. Comecei a fazer música mesmo a partir desse momento". Mas o compositor afirma que, a despeito da atitude de ruptura que é inerente à bossa nova, ela não o teria impossibilitado de buscar novas fontes para suas composições, principalmente aquelas situadas no período de criação do chamado "samba tradicional". Segundo Chico, a "ruptura total" durou apenas três ou quatro anos; depois disso, alguns dos mais importantes nomes da bossa nova retornam a Noel Rosa, Cartola e Nelson Cavaquinho, e passam a compor canções que já não podem se enquadrar na 
estética bossa-novista. ${ }^{5}$ O próprio Chico, no início de sua carreira, reedita Noel através de "Rita", samba que recria a atmosfera de dor-de-cotovelo e humor que caracteriza a sensibilidade do compositor de Vila Isabel, citado explicitamente na letra.

Se ampliamos, entretanto, o tema discutido para além do processo de composição, podemos analisar outros aspectos da bossa nova que influenciaram Chico Buarque, como, por exemplo, a maneira intimista de lidar com o palco, ao estilo de João Gilberto, recorrendo apenas ao "banquinho e violão". Chico admite que este tipo de estética se adequava à sua visão de artista, já que ele nunca se viu como um "artista de palco", "com fantasias, máscaras, figurinos e movimentação de palco", mas apenas como um "autor de músicas no palco". Assim, ao entrar no palco com a roupa que usa normalmente no cotidiano e ao cantar como se estivesse em casa, Chico registra a sua recusa de criar uma persona. Esta atitude, segundo ele, seria uma "reação de oposição absoluta à estética anterior, que era a estética do auditório de rádio, dos brilhos, do Cauby Peixoto, das grandes estrelas". A bossa nova, ao contrariar este tipo de extroversão, criou um cenário diferente, com "artistas que não eram artistas e cantores que não eram cantores". ${ }^{6}$

Edu Lobo assume uma atitude semelhante ao recusar não apenas a máscara, como também o palco, o que tem a ver com a sua identidade artística, construída basicamente a partir do trabalho de compositor. As outras atividades que desenvolve como instrumentista, orquestrador e intérprete seriam "ramificações" do seu trabalho. O palco, para ele, é uma exigência da profissão, ou, dito de outro modo, tem a ver com as condições do compositor no Brasil, em que se é praticamente obrigado a fazer show. ${ }^{7}$ Em termos propriamente musicais, Edu Lobo talvez seja o melhor exemplo de um compositor da geração 60 que dá continuidade à tradição inaugurada por Radamés na música popular. Além de compositor, Edu atua também como orquestrador, atividade para a qual se preparou durante dois anos nos Estados Unidos. E embora se considere um músico popular, tem uma formação técnica raramente vista neste domínio, responsável, em grande parte, pela sofisticação de suas harmonias e dos seus arranjos. Tal como
Radamés, ele aprecia um tipo de estética modernista mais exuberante, menos contida, como a de Ravel, Stravinsky, Bartók, Copland, Prokofiev - e, naturalmente, Villa-Lobos. Chega a questionar a ênfase excessiva que se dá ao jaž como elemento formador da bossa nova, pois este estilo musical sofreria também a influência de compositores mais antigos, principalmente Villa-Lobos. Assim, segundo Edu, as canções líricas da bossa nova - de Tom Jobim, Carlinhos Lyra e Baden Powell, entre outros — teriam "a alma do Villa". Como Chico Buarque, ele admite o impacto da "batida" do violão de João Gilberto sobre a sua música, embora veja o seu próprio trabalho como uma ramificação da bossa nova, já que, como outros músicos de sua geração, tende muito mais a misturar peças diferentes do repertório musical do que a lidar com um estilo claramente definido. É neste sentido que ele reconhece a ascendência de Villa-Lobos sobre a sua formação musical, cuja flexibilidade lhe serviria de parâmetro para misturar a informação que tinha de música nordestina - já que, por questões familiares, passava as férias em Recife até os 18 anos, ouvindo de tudo, "coisas populares, frevos e o que vinha da rua" - com toda a escola harmônica que tinha aprendido com a bossa nova. E é também a partir deste tipo de constatação que Edu Lobo, tal como Chico Buarque, ressalta a singularidade da geração a que pertence, formada imediatamente após à eclosão da bossa nova. Ao contrário de músicos mais ortodoxos ligados à nova tendência, que criavam, segundo Edu, uma fórmula para a bossa nova, alguns compositores começaram a abrir mais o estilo, entre eles Sérgio Ricardo, Carlos Lyra e Baden Powell. Esses músicos teriam começado "a perceber que o Brasil não é só o Rio de Janeiro". 8

Sem dúvida, o cenário musical assolado pela chamada "geração pós-bossa" não se esgota com as contribuições de Chico Buarque e Edu Lobo. Os dois compositores, entretanto, podem ser tomados como figuras emblemáticas desta geração, não só pela sua importância como formadores do gosto musical do período, como também por terem algo em comum; não por acaso, fizeram parcerias em várias composições. Apesar de Chico se destacar mais como cancionista, mostrando-se um hábil artesão ao trabalhar com música e letra, e Edu se 
especializar mais na composição de música — na maioria das vezes recorrendo a um parceiro letrista -, a sensibilidade de ambos parece convergir para uma certa leitura da tradição. Tanto um quanto o outro tendem, por exemplo, a valorizar e recuperar textos musicais legados pelo passado ou restritos a espaços geográficos específicos. Mais do que propriamente recorrer à citação, eles estruturam o seu trabalho a partir das informações colhidas após um longo período de escuta e análise. Dito de outro modo, é como se o procedimento de ambos se ancorasse na idéia de "recriação", tão familiar a certas tendências modernistas inclinadas a "filosofar em alemão". Edward Sapir, por exemplo, ligado ao grupo de antropólogos da Escola de Cultura e Personalidade norte-americana, lida de uma maneira muito particular com a questão da herança cultural. Fortemente fundamentado em Nietzsche, questiona, a propósito de se criar uma identidade nacional "saudável", a aceitação passiva do legado do passado. Assim, segundo Sapir, o processo criativo, por um lado, não significa a "manufatura da forma ex nibilo", isto é, a partir do zero, mesmo porque o indivíduo se tornaria "impotente" se não lançasse mão da herança cultural. Mas, por outro lado, a forma — legada pela tradição — deve ser submetida à "vontade" de alguém, pois "o passivo perpetuador de uma tradição cultural dá-nos simplesmente uma maneira, a casca de uma vida que passou" (Sapir, 1949, p. 299). Imbuídos de um espírito semelhante, os dois compositores citados - Chico Buarque e Edu Lobo - valorizam a tradição musical brasileira mas operam de modo a criar algo singular a partir do leque de opções disponíveis. Chico, por exemplo, ao retomar o samba urbano dos anos 30, tende a privilegiar as composições de Noel Rosa que tematizam a figura do músico-malandro como marginal e transgressor, o que se coaduna com sua postura contestadora, característica da segunda metade dos anos 60 .

Após esta passagem rápida por algumas das tendências predominantes na música brasileira nos anos 60, fica claro que todas elas - com exceção da bossa nova - apresentam uma característica comum: um procedimento que se pauta pela inclusão, muito próximo ao do bricoleur analisado por Lévi-Strauss. Chico Buarque e Edu Lobo, como vimos, optam pelo recurso à recriação, comum a uma certa tradição modernista que, afinada com o neo-romantismo alemão, mostra-se muita viva no pensamento modernista de Mário de Andrade. No Ensaio sobre a música brasileira, de 1928 (1962), Mário só vê a possibilidade de uma configuração cultural vital através da música — isto é, o desenvolvimento da "música artística" — a partir do aproveitamento do "populário" _ ou seja, as músicas folclórica e popular arraigadas na tradição nacional. Mas a plena realização da "música artística" requer, por outro lado, uma série de elaborações formais, o que significa uma transfiguração, para o registro erudito, das peças musicais fornecidas pela tradição; em outras palavras, trata-se de recriação.

Os músicos tropicalistas, na medida em que também operam com a idéia de inclusão, exibem de igual modo uma sensibilidade modernista. Só que, desta vez, a convergência se dá com Oswald de Andrade, com a sua predisposição para recolher — ou "devorar" — peças as mais díspares do repertório cultural, com o propósito de dispô-las em consonância com uma síntese coerente, porém não totalizante, à maneira do processo de colagem. Os baianos assumem também, à maneira de Oswald, a atitude antropofágica, devorando elementos arcaicos, vinculados à tradição, e modernos, associados às inovações técnicas. Do mesmo modo, as importações culturais são incorporadas sem qualquer temor de descaracterização de uma suposta pureza nacional, já que a cultura brasileira é vista como rica e pujante o suficiente para deglutir tudo que possa vir de fora: "Nunca fomos catequizados. Fizemos foi carnaval.” (Andrade, 1972, p. 16).

No movimento tropicalista, a tradição musical é valorizada, embora se faça um recorte diferente dos elementos culturais a serem utilizados. A concepção tropicalista de "riqueza cultural" abrange desde o rock alienígena aos ritmos regionais já consagrados, e mostra-se flexível o suficiente para incluir o kitsch como um item a mais do tesouro nacional. Amplia-se, portanto, a concepção de "riqueza cultural": além da criação mais "sofisticada", mesmo que produzida no registro popular, o esteticamente "pobre" também passa a ser precioso. A sofisticação aparece no processo de elaboração das músicas, nos arranjos meticulosos, nas 
performances, nas capas dos LPs - elementos que traem a influência das tendências progressistas do rock da época. Ao incorporar o impacto dos Beatles à sua estética, os tropicalistas estão atualizando o gesto da geração anterior, que dez anos antes utilizou, na elaboração da bossa nova, os procedimentos do jarz. mais avançado de seu tempo. $\mathrm{E}$ os tropicalistas assumem radicalmente $\mathrm{O}$ palco, encarnando publicamente, através de diversas máscaras e coreografias, o sincretismo que realizam entre os vários gêneros musicais. Da mesma forma em que há uma relação entre a sua estética e a imagem artística, música e letra, desde a concepção, mantêm entre si uma correspondência isomórfica. Os arranjos interferem com o mesmo peso. Guitarras elétricas, incorporadas do rock, convivem com a sonoridade kitsch dos violinos e com o berimbau da música regionalista. A guitarra elétrica, retirada do universo do rock e incorporada à cena tropicalista, aparece como símbolo de movimento cultural. Este instrumento ajuda a compor o espetáculo de roupas coloridas, cabelos encaracolados e apresentação cênica movimentada e parodística (Ribeiro, 1988).

O rock, porém, é apenas um de toda uma variedade de elementos díspares. Os tropicalistas lançam mão dos mais diversos textos e - o que é mais importante — os trabalham através de um exercício de metalinguagem, por meio da paródia ou do pastiche. Mas, mesmo valendo-se de procedimentos parodísticos e, portanto, críticos, não se trata de uma crítica corrosiva; a tradição costuma ser tratada com carinho: com "amor e humor", como diria Oswald de Andrade.

É carinhosa, por exemplo - e nada parodística —, a atitude adotada com relação à bossa nova, principalmente ao seu mentor, João Gilberto. Em "Saudosismo", canção-manifesto de 1969, Caetano proclama a retomada da linha dissonante inaugurada por João Gilberto:

$$
\begin{aligned}
& \text { Chega de saudade a realidade } \\
& \text { é que aprendemos com João } \\
& \text { pra sempre a ser desafinados }
\end{aligned}
$$

Mas, ao contrário da bossa nova, que se orienta por um modelo de contenção, a tropicália recorre ao excesso, retomando inclusive uma tradição que, como vimos, foi renegada pelos músicos bossa-novistas: os arranjos grandiosos de violinos e de metais inaugurados por Radamés e Pixinguinha, o estilo operístico de Francisco Alves, o ufanismo de "Aquarela do Brasil" e as dores-decotovelo derramadas que datam dos anos 20 e atravessam os anos 40 e 50, no samba-canção (Castro, 1991). Da mesma forma, os tropicalistas ressuscitam Vicente Celestino, considerado à época o modelo do mau gosto, e Chacrinha, associado ao grotesco, que se torna uma figura emblemática do movimento, saudado inclusive por Gilberto Gil na sua famosa canção de despedida, "Aquele abraço", de 1969. Duas tradições antagônicas foram assim incorporadas num mesmo movimento: a do despojamento, vinculada à bossa nova, e a do histrionismo do repertório popular tradicional. Os baianos inauguraram, portanto, com a tropicália, uma nova relação com a diferença, assumindo uma postura afirmativa e comprometendo-se de modo indiferenciado com todos os aspectos captáveis do universo brasileiro, como o brega e o cool, o nacional e o estrangeiro, o erudito e o popular, o rural e o urbano, e assim por diante.

A atitude tropicalista, portanto, rompe com o conceito de forma fechada - não existe uma fórmula de canção tropicalista, tal como uma fórmula de canção bossa-nova ou de samba-enredo -, incluindo indiscriminadamente os elementos destas diversas formas fechadas por vezes numa mesma canção. Em particular, o movimento faz questão de desconstruir a oposição mais fetichizada de todas as existentes no período: a que se faz entre o "nacional" e "autêntico", de um lado, e o "alienígena" e "descaracterizador", de outro. Daí as palavras compostas, fundindo um termo da cultura popular brasileira com um outro que representa a cultura de massa de origem norte-americana, como "batmacumba" e "bumba-iê-iê-boi". No plano musical, passo equivalente se dá aproveitando-se as coincidências rítmicas entre o rock e o baião, ambos em tempo binário fortemente marcado, com andamento rápido e relativamente pouco sincopado. Do mesmo modo, a tropicália se esforça por demolir outra oposição marcante: a que se dá entre a linguagem acessível da música popular 
e a metalinguagem erudita da crítica (e da literatura). As canções de Caetano, Gil e seus companheiros de movimento trabalham, tanto no plano da música quanto no da letra, com elementos "baixos" e "elevados": a sofisticação harmônica, melódica e poética de "Clara" convive com a singeleza irônica de "Baby"; e em "Alegria, alegria", uma letra que lança mão de recursos poéticos elaborados é acoplada a um iê-iê-iê fácil e despretensioso.

Retomo aqui o argumento apenas esboçado na conclusão do meu livro $O$ violão azul: modernismo e música popular, de que a atitude excludente do engenheiro dominou o cenário cultural brasileiro por um período curto e relativamente atípico. Num momento de afirmação da modernidade industrial do país, os ideais de funcionalidade e objetividade impuseram-se não apenas na arquitetura, nas artes plásticas e na música erudita - o dodecafonismo - como também na poesia e na música popular. Findo este momento de crença otimista nas virtudes da modernização do país, com as tensões e incertezas que marcaram o final dos anos 60, a estratégia do bricoleur — includente, flexível e assumidamente subjetivista e caprichosa - retoma a posição central que vinha mantendo desde o início do século.

\section{NOTAS}

1 Entrevista concedida aos pesquisadores do Centro de Estudos Sociais Aplicados (CESAP) da Universidade Candido Mendes em 25/6/1998.

2 Entrevista concedida aos pesquisadores do CESAP/ Universidade Candido Mendes em 9/10/1999.

3 Entrevista concedida a José Eduardo Homem de Mello em 17/10/1968. Apud Mello (1976, pp.15-18).

4 Entrevista concedida a José Eduardo Homem de Mello. Apud Mello (1976).

5 Entrevista concedida aos pesquisadores do CESAP/ Universidade Candido Mendes em 5/4/1999.

6 Entrevista concedida aos pesquisadores do CESAP/ Universidade Candido Mendes em 5/4/1999.

7 Entrevista concedida aos pesquisadores do CESAP/ Universidade Candido Mendes em 18/3/1999.

8 Entrevista concedida aos pesquisadores do CESAP/ Universidade Candido Mendes em 18/3/1999.

\section{BIBLIOGRAFIA}

ANDRADE, Mário de. (1962), Ensaio sobre a música brasileira. São Paulo, Livraria Martins Editora.

ANDRADE, Oswald de. (1972), "Manifesto antropófago", in Oswald de Andrade - Obras completas, Rio de Janeiro, Civilização Brasileira.

CABRAL, Sérgio. (1997), Antônio Carlos Jobim - uma biografia. Rio de Janeiro, Lumiar.

CAMPOS, Augusto de. (1968), Balanço da bossa: antologia crítica da moderna música popular brasileira. São Paulo, Perspectiva.

CASTRO, Ruy. (1991), Chega de saudade: a história e as bistórias da bossa nova. São Paulo, Companhia das Letras.

DERRIDA, Jacques. (1971), A escritura e a diferença. Tradução de Maria Beatriz Marques Nizza da Silva. São Paulo, Perspectiva.

DIDIER, Carlos. (1996), Radamés Gnattali. Rio de Janeiro, Brasiliana Produções.

LÉVI-STRAUSS, Claude. (1989), O pensamento selvagem. Tradução de Tânia Pellegrini. Campinas, Papirus.

MARIZ, Vasco. (1983), Três musicólogos brasileiros: Mário de Andrade, Renato Almeida, Luiz, Heitor Correa de Azevedo. Rio de Janeiro, Civilização Brasileira.

MELLO, José Eduardo Homem de. (1976), “Antônio Carlos Jobim”, in J.E. Homem de Mello, Música popular brasileira, São Paulo, Melhoramentos/Ed. da USP.

MOREIRA, Maria Micaela Bissio Neiva. (1999), "Do samba eu não abro mão": Chico Buarque nos anos 60. Monografia de final de curso de graduação, Departamento de Sociologia e Política da PUC-RJ, mimeo.

NAVES, Santuza Cambraia. (1998), O violão ažl: modernismo e música popular. Rio de Janeiro, Editora da Fundação Getúlio Vargas.

RIBEIRO, Santuza Cambraia Naves. (1988), Objeto não identificado: a trajetória de Caetano Veloso. Dissertação de mestrado, Programa de Pós-Graduação em Antropologia Social, Museu Nacional, Universidade Federal do Rio de Janeiro.

SAPIR, Edward. (1949), "Cultura 'autêntica' e 'espúria"”, in Donald Pierson (org.), Estudos de organiz̧ação social, tradução de Asdrúbal Mendes Gonçalves, São Paulo, Livraria Martins Editora.

WISNIK, José Miguel. (1983), O coro dos contrários: a música em torno da Semana de 22. $2^{\text {a }}$ ed., São Paulo, Duas Cidades. 